\title{
PERANAN TEKNOLOGI INFORMASI DALAM PENYEDERHANAAN PROSES PENYAJIAN INFORMASI: STUDI KASUS PRODUKSI DAN PERSEDIAAN PT SSAM
}

\author{
Suparto Darudiato ${ }^{1}$ \\ ${ }^{1}$ Jurusan Sistem Informasi, Fakultas Ilmu Komputer, Universitas Bina Nusantara, \\ Jl. K.H. Syahdan No. 9, Kemanggisan/Palmerah, Jakarta Barat 11480 \\ supartod@binus.edu
}

\begin{abstract}
Article to analyse the selling information needs by paying attention to transaction simplicity process so it can grow the custmer trust to the company. The research was done by a direct survey to the company by doing business process survey, spreading questioner, and analyzing the needs of information. The research result was problems list and the user needs of information.
\end{abstract}

Keywords: information technology, information dissemination, inventory, production

\begin{abstract}
ABSTRAK
Artikel menganalisis kebutuhan informasi penjualan dengan memperhatikan penyederhanakan proses transaksi sehingga dapat menumbuhkan tingkat kepercayaan pelanggan terhadap perusahaan. Penelitian ini dilakukan dengan cara survei langsung ke perusahaan dengan melakukan pengamatan proses bisnis, menyebarkan kuesioner, dan melakukan analisis kebutuhan informasi. Hasil penelitian ini berupa daftar permasalahan dan kebutuhan informasi.
\end{abstract}

Kata kunci: teknologi informasi, penyajian informasi, persediaan, produksi

\section{PENDAHULUAN}

Pada masa lalu, perencanaan yang dilakukan oleh perusahaan banyak dilandaskan pada kemampuan serta pertimbangan kondisi internal yang ada. Dengan perkembangan dunia bisnis yang semakin maju menimbulkan persaingan yang sangat ketat diantara pelaku bisnis sehingga untuk menghadapi persaingan tersebut bukan hanya produk dan harga yang menjadi jaminan tetapi mutu pelayanan juga merupakan salah satu faktor dalam persaingan tersebut. Untuk mencapai hasil bisnis yang baik dan menarik peluang pasar yang baik serta membuat perusahaan menjadi dapat bersaing, diperlukan tunjungan informasi dan strategi perusahaan yang baik dalam mencapai misi perusahaan.

Setiap pelaku bisnis saat ini harus lebih mengarahkan pemikiran guna memahami kecenderungan lingkungan serta perubahan yang diperkirakan akan terjadi dalam lingkungan industri tempat perusahaan tersebut menjalankan bisnisnya.
Dengan persaingan bisnis yang semakin tajam maka kondisi yang perlu dipertimbangkan bukan saja faktor internal tetapi juga faktor eksternalnya. Selain perubahan pesaing dan teknologi informasi, dunia usaha juga menemui perubahan dalam perilaku konsumen. Pelanggan yang tadinya begitu setia dengan satu produk, sekarang beralih ke produk lain yang menjanjikan kemudahan. Dewasa ini, pelanggan menuntut pelayanan yang baik, mutu yang baik, harga murah, dan lain-lain yang dapat memberikan kemudahan tersebut.

PT SSAM adalah sebuah perusahaan yang bergerak dalam bidang tekstil. Tujuan perusahaan adalah dapat melakukan pengiriman barang sesuai dengan pesanan dari pelanggan dan dapat menghadapi tuntutan pelanggan mengenai mutu barang dengan bijaksana, dengan harapan image perusahaan akan lebih baik sehingga perusahaan dapat meningkatkan penjualan. Dengan demikian, keuntungan perusahaan akan meningkat. Bisnis tekstil di Indonesia saat ini sedang dalam keadaan krisis. Oleh sebab itu, jika perusahaan menghendaki dapat bertahan dan melakukan persaingan di dalam 
negeri maupun di luar negeri maka perusahaan harus meninjau kembali proses bisnis secara radikal.

Pengaturan strategi untuk menghadapi masa yang akan datang dikaitkan dengan keputusan yang diambil oleh manajemen untuk mencapai sasaran yang diinginkan. Keputusan yang diambil oleh manajemen harus didukung dengan informasi dan analisis, untuk manajemen dalam meningkatkan strategi. Dengan persaingan yang semakin ketat, dibutuhkan suatu sistem baru yang fleksibel dan dinamis sehingga mampu bersaing dimasa yang akan datang. Dengan berubahnya proses bisnis maka sistem yang tadinya dirancang secara vertikal harus ditinggalkan karena sudah tidak mampu mengantisipasi perubahan. Perusahaan harus ditata sedemikian rupa sehingga mampu mengantisipasi dan mampu menghadapi tantangan masa depan. Penataan ini dapat dilakukan dengan merekayasa ulang proses bisnis yang sasaran dan proses berjalannya perusahaan didefinisikan, ditata, dan dirancang kembali.

\section{PEMBAHASAN}

Manajemen strategi merupakan kumpulan keputusan dan tindakan yang menghasilkan formulasi dan implementasi rencana yang didesain untuk mencapai tujuan suatu perusahaan. Karena manajemen strategis mencakup pengambilan keputusan jangka panjang, berorientasi masa yang akan datang, dan rumit, serta memerlukan sumber daya yang diperlukan, maka partisipasi manajemen puncak adalah penting.

Mengelola aktivitas internal perusahaan hanya sebagian dari tanggung jawab eksekutif modern. Eksekutif modern harus menanggapi tantangan yang disebabkan oleh kondisi ekonomi dan sosial, prioritas politik, dan pengembangan teknologi, yang semuanya harus diantisipasi, dimonitor, dinilai, dan digabungkan ke dalam pengambilan keputusan eksekutif.

Manajemen strategis meliputi perencanaan, pengarahan, pengorganisasian, dan pengendalian keputusan dan tindakan yang berhubungan dengan strategi perusahaan. Suatu strategi merefleksikan kesadaran suatu perusahaan mengenai bagaimana, kapan, dan dimana perusahaan akan bersaing. Manajemen strategis mencakup aliran keputusan, pengembangan strategi yang efektif, cara pembuat strategi membuat keputusan, dan desain keputusan serta program.

Keputusan usaha membantu untuk menjembatani keputusan pada tingkat korporat dan fungsional. Keputusan demikian lebih murah, kurang mempunyai risiko, dan secara potensial kurang menguntungkan daripada keputusan tingkat korporat. Akan tetapi, keputusan usaha lebih mahal, lebih mempunyai risiko, dan secara potensial lebih menguntungkan dibandingkan dengan keputusan tingkat fungsional.

Analisis Rantai Nilai adalah semua kegiatan atau aktivitas usaha dapat dirumuskan dalam Analisis Rantai Nilai yang dikelompokkan dalam kelompok kegiatan aktivitas. Mengembangkan rantai nilai dan menganalisis aktivitas nilai secara rinci memberikan analis suatu pemahaman mengenai bagaimana suatu organisasi melaksanakan aktivitasnya, bagaimana aktivitas berinteraksi, dan apa kepentingan relatif dari setiap aktivitas tersebut. Rantai nilai terdiri dari aktivitas utama (Primary activities) dan aktivitas pendukung (Support activities), seperti tertera pada Gambar 1.

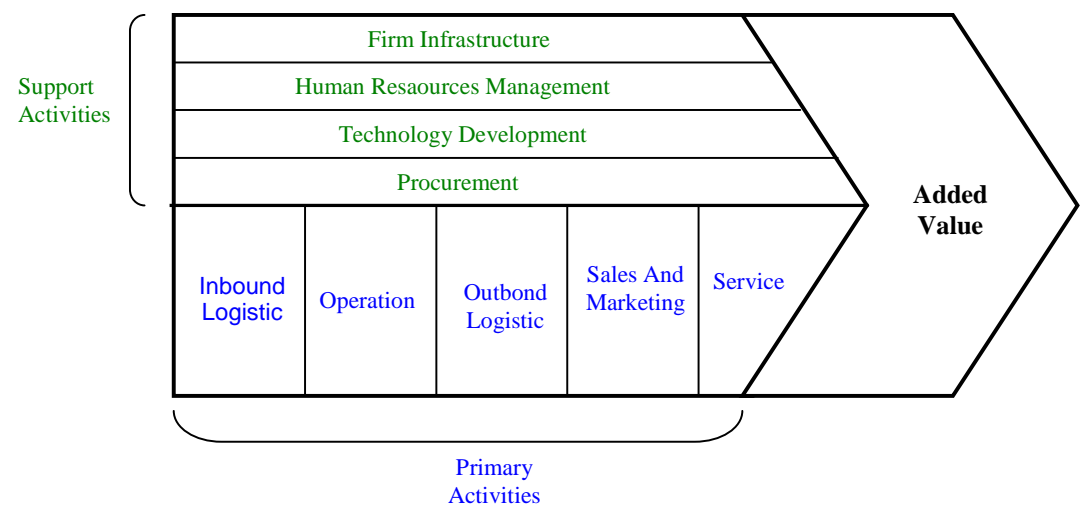

Sumber: Michael E. Porter, Competitive Advantage (1985:39, New York: Free Press)

Gambar 1 Rantai Nilai 
Bisnis Proses Engineering atau rekayasa ulang adalah pemikiran ulang secara fundamental/ mendasar dan perancangan ulang secara radikal dari suatu sistem bisnis secara keseluruhan yang meliputi: proses bisnis, pekerjaan, struktur organisasi, sistem manajemen, nilai, dan keyakinan, untuk mencapai suatu perbaikan yang dramatis dalam hal ukuran kinerja yang penting dan kontemporer yang meliputi biaya, kualitas, pelayanan, dan kecepatan. Di dalam Rekayasa Ulang perlu dilihat secara berikut ini. Pertama, mendasar. Dalam melakukan rekayasa ulang proses bisnis, harus mengajukan yang paling mendasar yang berkaitan dengan perusahaan dan bagaimana mengoperasikannya. Perusahaan harus mampu menemukan apa yang harus dilakukan oleh perusahaan dan kemudian menentukan bagaimana melakukannya. Perekayasaan ulang memerlukan peninjauan atas proses bisnis dari perspektif antarfungsi. Hal itu adalah sesuatu yang fundamental dan melibatkan staf dari berbagai departemen yang berkaitan dalam perekayasaan proses.

Kedua, radikal. Hal yang dimaksud dengan perencanaan kembali secara radikal adalah perencanaan ulang dengan mendasarkan pada akar permasalahan. Dalam rekayasa ulang, perencanaan kembali secara radikal dimaksudkan tidak memperhatikan struktur dan prosedur yang sudah ada sekarang tetapi menciptakan cara yang sama sekali baru secara keseluruhan/lengkap dalam menyelesaikan pekerjaan.

Ketiga, dramatik. Rekayasa ulang bukan tentang upaya mencapai peningkatan secara marginal ataupun inkremental tetapi tentang pencapaian suatu lompatan besar dalam hal performasi/kinerja puncak perusahaan. Untuk mencapai peningkatan secara marginal, dibutuhkan upaya perbaikan secara terus menerus. Perbaikan dramatis meminta membuang yang lama dan menggantikan dengan yang baru. Keempat, proses. Sebagian besar kalangan bisnis tidak "berorientasi pada Proses” tetapi berfokus pada tugas, pekerjaan, orang, struktur, tetapi tidak pada proses.

Dari batasan tersebut dapat dilihat bahwa Rekayasa Ulang adalah totalitas upaya kilat yang radikal dari suatu organisasi untuk meraih peningkatan nilai yang berorientasi pada kepuasan pelanggan. Hal itu semua harus dimulai dari sisi strategi sehingga optimasi arus kerja fungsional untuk perbaikan kualitas produk/jasa dan masalah produktivitas. Beberapa sifat yang paling mendasar dan paling umum dari proses yang telah direkayasa ulang adalah tidak adanya perakitan. Artinya beberapa tugas antara pekerjaan yang awalnya terpisah diintegrasikan dan dipadatkan menjadi satu.
Perusahaan yang menjalankan rekayasa ulang tidak hanya memadatkan proses secara horisontal dengan membentuk pelaksana kasus atau tim kasus yang melaksanakan tugas ganda dan bergiliran tetapi juga secara vertikal. Pemadatan secara vertikal berarti bahwa hal yang biasanya harus ditanyakan oleh para pekerja secara hierarki managerial, sekarang dapat mereka putuskan sendiri. Persediaan dapat terdiri dari berbagai bentuk yang berbeda, tergantung daripada sifat kegiatan usaha. Untuk perusahaan pengecer dan grosir, jenis persediaan yang paling penting adalah barang dagangan sedangkan untuk perusahaan manufaktur persediaan dapat teridri atas bahan baku, barang dalam proses produksi, dan barang jadi yang siap dijual.

Ada dua macam metode dalam pencatatan persediaan, yaitu Metode Mutasi Persediaan dan Metode Persediaan Fisik. Dalam sistem akuntansi secara manual, proses pencatatan persediaan diselenggarakan dalam dua catatan akuntansi, yaitu pada fungsi gudang dan fungsi akuntansi. Pada fungsi gudang, hanya mencatat mutasi berkuantitas fisik persediaan dan harga pokok persediaan tidak dicatat sedangkan pada fungsi akuntansi, baik mutasi kuantitas fisik persediaan juga harga pokok persediaan dicatat dalam kartu persediaan.

Dari kedua metode perncatatan persedian terdapat beberapa metode yang digunakan untuk perhitungan harga pokok persediaan: Masuk Pertama Keluar Pertama (MPKP) atau First In First Out (FIFO); Masuk Terakhir Keluar Pertama (MTKP) atau Last In First Out (LIFO); Harga Pokok RataRata. Di dalam perencanaan dan pengendalian persediaan ada dua hal yang harus diperhatikan yang merupakan sasaran yang akan dicapai, yaitu mengurangi biaya keseluruhan atau memperbesar laba dengan alokasi sumber daya tertentu.

Perencanaan persediaan berkaitan dengan dua faktor mendasar, yaitu kuantitas dan saat pembelian. Penentuan kuantitas yang harus dibeli dan kapan harus memberi melibatkan dua jenis biaya, yaitu biaya pemilikan dan biaya akibat tidak memadainya persediaan. Kedua jenis biaya itu saling bertentangan sehingga harus ada pertimbangan akan berapa kuantitas pesanan yang ekonomis. Kaitan kedua hal tersebut adalah dilihat dengan istilah kuantitas pesanan yang ekonomis. Untuk menghitung kuantitas pesanan yang ekonomis, dapat digunakan suatu formula, seperti dalam Rumus 1 . 
Rumus 1.

$$
N=\sqrt{\frac{2 \mathrm{AP}}{\mathrm{RC}}}
$$

Keterangan:

$\mathrm{N}=$ Economic Order Quantity (Kuantitas pesanan yang ekonomis)

= Annual Require Units (Unit kebutuhan setahun)

= Cost per Order (Biaya per pesanan)

= Cost per unit of material (Harga barang per unit)

$=$ Carrying cost percentage (Biaya penyimpanan)

Formula EOQ dapat memecahkan masalah kuantitas dalam pengendalian persediaan, namun kapan untuk melakukan pemesanan juga sama pentingnya. Masalah itu dikendalikan oleh tiga faktor, yaitu selang waktu yang diperlukan untuk pengiriman barang pesanan (lead time); Tingkat pemakaian/ penjualan persediaan; Persediaan pengaman.

Pengendalian persediaan harus memenuhi dua kebutuhan, yaitu menjaga persediaan dalam kuantitas dan keragaman yang memadai untuk operasi yang efisien dan menjaga persediaan yang menguntungkan secara keuangan.

Untuk mencapai suatu tingkat pengendalian yang efektif, perlu adanya suatu teknik yang dapat membuat dan menjaga pengendalian tetap efektif. Kita dapat menggunakan teknik ratio untuk mengetahui seberapa besar perputaran dari suatu persediaan untuk suatu periode tertentu. Ratio itu dapat dihitung dengan Rumus 2.

Suatu ratio perputaran persediaan yang rendah menandakan bahwa terdapat over investment. Tingkat perputaran memegang peranan tertentu dalam menilai efisiensi dan peningkatan perputaran bukan dipandang sebagai tujuan akhir. Untuk memungkinkan sebuah pabrik dapat bekerja sebagaimana yang diharapkan, dibutuhkan adanya kegiatan pengendalian atas produksi agar penyimpangan yang terjadi dapat segera diketahui dan diperbaiki.

Pengendalian produksi bertugas merintis dan mengawasi aliran pekerjaan dalam sebuah pabrik sehingga terdapat kemajuan dalam pekerjaan dengan cara yang sistematis dari suatu bagian ke bagian lain tanpa danya kemacetan atau keterlambatan. Pengendalian produksi dilakukan tergantung dari jenis proses produksi. Proses produksi terdiri dari dua jenis, pertama proses produksi yang terus menerus. Pada prose produksi yang terus menerus ini, pengendalian produksi terdiri dari dua jenis utama, yaitu Flow Control dan Order Control. Kedua, proses produksi yang terputus-putus. Dalam proses produksi yang terputus-putus, sistem pengendalian prosuksi yang dijalankan adalah Order Control.

\section{Permasalahan yang Dihadapi}

Sejak berdirinya perusahaan PT SSAM sampai sekarang, belum pernah dilakukan peninjauan kembali atas proses bisnis yang berjalan. Manajemen perusahaan seolah-olah hanya mengikuti arus pasar saja, sementara persaingan di pasar semakin ketat dan mengalami gejolak dan perubahan ekonomi yang tidak kecil

Permasalahan yang dihadapi sebagai berikut. Pertama, saat ini perusahaan sudah merasa berat untuk bersaing di luar karena biaya produksi yang semakin tinggi, arus informasi yang tidak lancar, serta banyak bagian yang seharusnya terkait tetapi bekerja sendiri-sendiri. Kedua, penyediaan bahan baku tidak lancar sehingga sering kali menghambat jalannya produksi. Karena sering terjadi tidak tersedianya bahan baku, secara otomatis penyelesaian akan sebuah pesanan akan tertunda. Hal itu menimbulkan masalah yang cukup serius dengan dibatalkannya pesanan. Ketiga, arus pengiriman barang kurang lancar.

H Disebabkan karena keterlambatan produksi yang mengakibatkan keterlambatan pengiriman barang.

$\mathrm{H}$ Kurang telitinya bagian cek mutu dalam melakukan pemeriksaan barang serta salah masuk gudang sehingga sering terjadi barang dikembalikan.

$\mathrm{H}$ Cukup banyak barang yang dikembalikan karena barang yang dikirim tersebut telah dibatalkan sebelumnya oleh pelanggan. Hal itu terjadi karena tidak adanya koordinasi antara bagian pengiriman denga bagian penjualan.

$\mathrm{H}$ Tidak adanya jadwal pengiriman barang sehingga sulit untuk mendapatkan truk

Rumus 2

Perputaran Persediaan

Rata - rata Persediaan

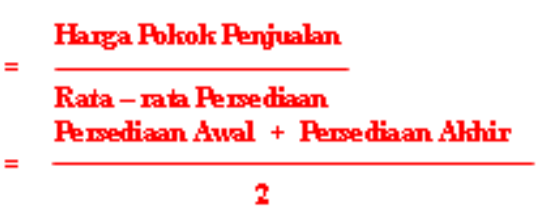


yang dibutuhkan dalam pengiriman barang tersebut dengan waktu yang mendadak. Kasus itu akan menimbulkan biaya pengiriman yang tinggi, akibat dari pemakaian kendaraan yang seadanya.

Peran produk sendiri sangat penting dalam menentukan keberhasilan pemasaran, terutama yang menyangkut kualitas. Di samping itu, untuk melihat apakah ada kemungkinan untuk mengembangkan produk jenis lain lebih lanjut sehingga produk tersebut benar-benar dapat memenuhi kebutuhan pelanggan.
Dengan mengetahui faktor sukses kritis ini diharapkan manajemen dapat memfokuskan aktivitas yang paling penting dalam kegiatan yang menunjang jalannya proses bisnis. Dengan demikian, manajemen dapat menganalisis masalah dan pengambilan keputusan dengan tepat, cepat, dan akurat. Di samping itu, faktor sukses kritis dapat memebantu untuk memenuhi kebutuhan informasi yang perlu segera dipenuhi. Tabel CSF dapat dibuat, seperti terlihat pada Tabel 1.

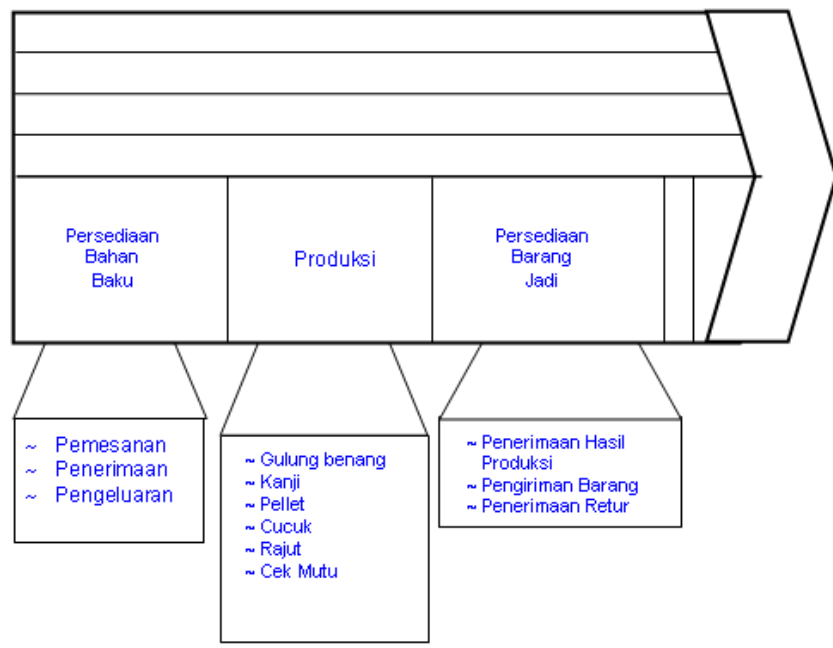

Gambar 2 Analisis Rantai Nilai (Hasil Wawancara dan Analisis) Kasus Produksi dan Persediaan pada PT SSAM

Tabel 1 Analisis Critical Succes Factor (Hasil Wawancara dan Analisis)

\begin{tabular}{|c|c|c|}
\hline Objective & & \\
\hline \multicolumn{3}{|c|}{$\begin{array}{l}\text { - Meringkatkan Produksi } \\
\text { * Meringkatkan pendapatan i penjualan }\end{array}$} \\
\hline Goal & C S F & Kebutuhan Informasi \\
\hline $\begin{array}{l}\text { Pengendalian } \\
\text { Persediaan Bahan } \\
\text { Baku }\end{array}$ & $\begin{array}{l}\text { * Persediaan Minimurn } \\
\text { * Ketersediaan bahan baku } \\
\text { * Mutu bahan baku }\end{array}$ & $\begin{array}{l}\text { * Laporan Persediaan Mirimurn } \\
\text { * Laporan Persediaan } \\
\text { * Analisis Pernasok } \\
\text { * Laporan Penerimaan Barang } \\
\text { * Laporan Retur }\end{array}$ \\
\hline Pengawasan Produksi & $\begin{array}{l}* \text { Kepuasan pelanggan } \\
\text { * Mutu produksi } \\
\text { * Produksi tepat waktu } \\
\text { * Biaya produksi yang rendah } \\
\text { * Rencana pernakaian bahan baku } \\
\text { * Kesatuar Informasi }\end{array}$ & $\begin{array}{l}\text { * Rencara Produksi } \\
\text { * Laporar Produksi } \\
\text { * Alokasi Bahar Baku } \\
\text { * Laporar Satus Produksi }\end{array}$ \\
\hline $\begin{array}{l}\text { Pengendalian } \\
\text { Persediaan Barang } \\
\text { Jadi }\end{array}$ & $\begin{array}{l}* \text { Kesesuaian pengiriman barang dengan } \\
\text { pesanan } \\
\text { * Kebenaran barang yang diterima (retur) } \\
\text { * Pengiriman yang tepat waktu } \\
\text { * Ketepatan pengiriman barang }\end{array}$ & $\begin{array}{l}\text { * Laporan Persediaan } \\
\text { * Laporan Pengiriman Barang } \\
\text { * Laporar Penerimaan Barang } \\
\text { * Jadwal Pengiriman }\end{array}$ \\
\hline
\end{tabular}


Pemilihan CSF yang dikehendaki oleh responden memiliki alasan tersendiri, berikut analisis CSF tersebut: Di dalam pemilihan pemasok kita perlu meninjau beberapa hal untuk menentukan kepada siapa kita harus memesan barang. Hal yang perlu dipertimbangkan adalah harga, ketepatan pengiriman, mutu barang (dilihat dari retur), jumlah discount, dan lamanya waktu pembayaran (terlihat dalam Tabel 2).

\section{PENUTUP}

Dari hasil pengamatan di lapangan, wawancara dengan orang yang terlibat dalam proses, dan hasil kuesioner yang disebarkan, dapat disimpulkan bahwa PT SSAM sudah saatnya melakukan Rekayasa Ulang Proses Bisnisnya untuk menghadapi tantangan pasar yang semakin ketat. Dengan berdasarkan pada hasil pengamatan, wawancara, dan kuesioner yang diterima terlihat bahwa banyak faktor kritis yang akan mempengaruhi jalannya bisnis, tidak terlihat oleh manajemen. Dari hasil analisis rantai nilai dan Critical Success Factor, dibuat usulan kebutuhan informasi dengan system informasi berbasis komputer yang mendukung proses produksi dan persediaan.

Dari prototipe yang dilakukan dilokasi yang berhubungan dengan produksi dan persediaan, terlihat pada sistem tersebut sangat memerlukan Teknologi Informasi untuk membantu pekerjaan mereka. Hanya saja peneliti tidak sempat untuk menyebarkan kuesioner kepada mereka untuk mendapat umpan balik.

\section{DAFTAR PUSTAKA}

Andrew, Dorine C. and Susan K. Stalick. 1994. Business Reengineering: The Survival Guide. London: Prentice Hall.

Earl, Michael J. 1989. Management Strategies for Information Technology. New Jersey: Prentice Hall, Englewood Cliffs.

Harjanto, Djunaidi. 1994. "Mengukur Pengaruh Teknologi Informasi Atas Fungsi Produksi.” Jurnal Manajemen Prasetya Mulya Volume 11 Nomor 1.

Hammer, Michael and Steven Staton. 1994. The Reengineering Resolution. New York: Harper Collins Publisher.

Johansson, Hery J., et. al. 1993. Business Process Reengineering. USA: John Wiley \& Sons Ltd.

Kotler, Philip. 1994. Marketing Management Analysis Planning, Implementation, and Control. Eight Edition. New York.

Levin, I. Richard, et. al. 1993. Quantitive Approaches to Management. 8th Edition. McGraaw Hill Inc.

Martin, James. 1990. Information Engineering. Book I. New Jersey: Prentice Hall, englewood Cliffs.

Martin, James. 1990. Information Enggineering. Book II. Englewood Cliffs, New Jersey: Prentice Hall.

Tabel 2 Penentuan Ranking Pemasok (Hasil Wawancara dan Analisis)

\begin{tabular}{llllll}
\hline \multirow{2}{*}{ Kegiatan yang dinilai } & \multicolumn{5}{c}{ Point } \\
\cline { 2 - 6 } & \multicolumn{2}{c}{$\mathbf{5}$} & \multicolumn{4}{c}{$\mathbf{4}$} & \multicolumn{1}{c}{$\mathbf{2}$} & \multicolumn{1}{c}{$\mathbf{~}$} \\
\hline Harga & Paling murah & Kedua & Ketiga & Keernpat & Kelima \\
Ketepatan waktu pengiriman & Tepat & Telat 1 hari & Telat 2-3 hari & Telat 45 hari & Telat $>5$ hari \\
Persentasi Retur & $0 \%$ & $10 \%$ & $20 \%$ & $30 \%$ & $>40 \%$ \\
Tingkat Potongan & Tertinggi & Kedua & Ketiga & Keernpat & Kelima \\
Lama Kredit & $>35$ hari & $26-35$ hari & $15-25$ hari & $7-14$ hari & $<7$ hari \\
\hline
\end{tabular}

\begin{tabular}{|c|c|c|c|}
\hline Kegiatan yang dinilai & Bobot & Nilai & (Bobot * Point) \\
\hline Harga & 100 & & 9,999 \\
\hline Ketepatan waktu pengiriman & 50 & & 9,999 \\
\hline Persentasi Retur & 200 & & 9,999 \\
\hline Tingkat Potongan & 25 & & 9,999 \\
\hline Lama Kredit & 75 & & 9,999 \\
\hline
\end{tabular}


Mcleod, Raymond. 2005. Management Information Systems. 9th Edition. Englewood Cliffs, New Jersey: Prentice Hall.

Pearch, John A. and Richard B. Robinson Jr. 1991. Strategic Management Formulation, Implementation, and Control. 4th Edition. Richard D. Irwin Inc., Boston.

Porter, ME. 1990. Competitive Strategy. New York: Free Press.

1993. Competitive Advantage. Collier Macmillan Publisher. 